\title{
ANALISIS PENGARUH KUALITAS AKTIVA PRODUKTIF DAN KREDIT BERMASALAH TERHADAP PROFITABILITAS (STUDI EMPIRIS PADA BANK PEMBERI KREDIT YANG TERDAFTAR DI BEI)
}

\author{
Sugiyanti \\ Heriston Sianturi, SE.,MM \\ Program Studi Fakultas Ekonomi Universitas Satya Negara Indonesia
}

\begin{abstract}
ABSTRAK
Tujuan dari penelitian ini adalah untuk mengetahui apakah pengaruh kualitas aktiva produktif dan kredit bermasalah berpengaruh terhadap profitabilitas. Obyek penelitian meliputi Bank Pemberi Kredit yang terdaftar di BEI dengan sampel 60 laporan keuangan periode tahun 2008-2012.

Hasil dari analisis menunjukan bahwa kualitas aktiva produktif dan kredit bermasalah mempunyai pengaruh terhadap profitabilitas hanya saja tidak signifikan, hal ini disebabkan banyak faktor lain yang juga mempengaruhi. Karena kegiatan bank tidak hanya memberikan kredit, ada transaksi lain yang juga mempengaruhi profitabilitas seperti menghimpun dana dari masyarakat dalam bentuk simpanan dan menyalurkannya kepada masyarakat dalam bentuk kredit dan atau bentuk-bentuk lainnya dalam rangka meningkatkan taraf hidup rakyat banyak juga pembelian suratsurat berharga, penyertaan, pemilikan harta tetap dan transaksi lainnya.
\end{abstract}

Kata kunci : Aktiva produktif, kredit bermasalah, profitabilitas. 


\section{PENDAHULUAN}

Perbankan memiliki peranan yang sangat strategis dalam menunjang berjalannya roda perekonomian dan pembangunan nasional mengingat fungsinya sebagai lembaga intermediasi, penyelenggara transaksi pembayaran, serta alat transmisi kebijakan moneter atau sebagai development agent. Hal ini dapat dilihat ketika sektor ekonomi mengalami penurunan maka salah satu cara mengembalikan stabilitas ekonomi adalah menata sektor perbankan. Keuntungan yang diperoleh setiap perusahaan perbankan sebagian besar berasal dari bunga pinjaman yaitu sebagai hasil dari diberikannya sejumlah kredit kepada para nasabahnya atau debitur.

Kredit adalah penyediaan uang atau tagihan berdasarkan persetujuan atau kesepakatan pinjam meminjam antara bank dengan pihak lain yang mewajibkan pihak peminjam untuk melunasi kewajibannya setelah jangka waktu tertentu dengan jumlah bunga, imbalan atau pembagian hasil keuntungan (S.Harjadi,2013).

Tujuan dari adanya penyediaan kredit bagi bank adalah pengembalian kredit yang menghasilkan bunga dan dapat meningkatkan pendapatan untuk pembiayaan kegiatan dan kontinuitas usahanya.

Tingkat pengembalian kredit juga dapat menggambarkan kondisi kredit bermasalah yang dapat mempengaruhi besarnya pencadangan aktiva produktif dan berpengaruh juga pada modal bank itu sendiri. Apabila tingkat pengembalian kredit menurun maka akan memperbesar kredit bermasalah dan memperbesar pencadangan aktiva produktif yang pada akhirnya dapat mengurangi modal bank.

Aktiva produktif merupakan asset yang dimiliki oleh bank, dimana penggunaannya dilakukan dengan cara penanaman dana dalam bentuk rupiah maupun valuta asing, kredit yang diberikan, surat berharga yang diterbitkan serta penempatan pada bank lain. Kualitas aktiva produktif bank dinilai berdasarkan kolektibilitasnya, yang pada prinsipnya didasarkan pada kontinuitas pembayaran kembali pokok dan bunga serta kemampuan peminjam yang ditinjau dari keadaan usaha yang bersangkutan. Aktiva yang produktif sering juga disebut dengan earning assets atau aktiva yang menghasilkan, karena penanaman dana tersebut dalah untuk mencapai tingkat penghasilan (laba) yang diharapkan. Penilaian asset suatu bank cenderung kepada penilaian Kualitas Aktiva Produktif (KAP) untuk lebih mengetahui sejauh mana kualitas aktiva yang dimiliki sebagai salah satu faktor pendukung dalam menghasilkan laba pada suatu bank.

Salah satu cara yang dapat digunakan untuk mengukur kinerja keuangan bank adalah dengan analisis profitabilitas. Tingkat profitabilitas perusahaan perbankan menunjukkan pendapatan yang mampu dihasilkan oleh suatu bank dalam satu atau setiap periode dimana salah satu pendapatannya diperoleh dari pendapatan bunga yang dihasilkan oleh pengembalian kredit, maka secara tidak langsung pengembalian kredit mempunyai peranan yang sangat penting dalam memberikan pendapatan bagi bank.

Dapat disimpulkan bahwa tingkat profitabilitas merupakan aspek yang mencerminkan kemampuan setiap perusahaan untuk menghasilkan laba. Tingkat 
profitabilitas merupakan salah satu elemen penting dalam penilaian kinerja keuangan bank. Bank harus selalu menjaga tingkat profitabilitasnya untuk kontinuitas usahanya.

Faktor-faktor yang mempengaruhi profitabilitas Bank dapat bersumber dari berbagai kinerja operasi yang ditunjukkan beberapa indikator. Salah satu indikator utama yang dijadikan dasar penilaian adalah laporan keuangan Bank yang bersangkutan.

\section{Perumusan Masalah}

Aktiva produktif merupakan asset yang dimiliki oleh bank, dimana penggunaannya dilakukan dengan cara penanaman dana dalam bentuk rupiah maupun valuta asing, kredit yang diberikan, surat berharga yang diterbitkan serta penempatan pada bank lain. Kualitas aktiva produktif bank dinilai berdasarkan kolektibilitasnya, yang pada prinsipnya didasarkan pada kontinuitas pembayaran kembali pokok dan bunga serta kemampuan peminjam yang ditinjau dari keadaan usaha yang bersangkutan. Penilaian asset suatu bank cenderung kepada penilaian Kualitas Aktiva Produktif (KAP) untuk lebih mengetahui sejauh mana kualitas aktiva yang dimiliki sebagai salah satu faktor pendukung dalam menghasilkan laba pada suatu bank dengan salah satu indikator pengukurannya dengan analisis profitabilitas. Dengan demikian perumusan masalah dalam penelitian ini yaitu apakah terdapat pengaruh kualitas aktiva produktif dan kredit bermasalah terhadap profitabilitas pada bank pemberi kredit yang tetrdaftar di Bursa Efek Indonesia (BEI).

\section{LANDASAN TEORI}

\section{Aktiva Produktif}

Aktiva produktif adalah semua bentuk aktiva dalam bentuk rupiah dan valuta asing yang dimiliki bank yang digunakan untuk memperoleh hasil (pendapatan) sesuai dengan fungsinya (S.Harjadi, 2013).

Kualitas aktiva Produktif (KAP) adalah sebagai nilai tingkat kemungkinan diterimanya kembali dana yang ditanamkan dalam aktiva produktif (pokok termasuk bunga) berdasarkan kriteria tertentu. Hal ini untuk memudahkan dalam memahami aktiva produktif dalam pembahasan selanjutnya. Aktiva diartikan sebagai jasa yang akan datang dalam bentuk uang atau jasa mendatang yang dapat ditukarkan menjadi uang (kecuali jasa-jasa yang timbul dari kontrak yang belum dijalankan kedua belah pihak secara sebanding) yang didalamnya terkandung kepentingan yang bermanfaat yang dijamin menurut hukum atau keadilan bagi orang atau sekelompok orang tertentu. Aktiva juga diartikan sebagai manfaat ekonomi yang sangat mungkin diperoleh atau dikendalikan oleh entitas tertentu pada masa mendatang sebagai hasil transaksi atau kejadian masa lalu.

Penilaian tingkat kesehatan bank tersebut di atas dikenal dengan metode CAMEL meliputi 5 aspek yaitu: 
1. Capital, untuk rasio kecukupan modal

2. Assets, untuk rasio kualitas aktiva

3. Management, untuk menilai kualitas manajemen

4. Earnings, untuk rasio - rasio rentabilitas bank

5. Liquidity, untuk rasio - rasio likuiditas bank

Dari aspek kualitas aset ini merupakan penilaian jenis - jenis aset yang dimiliki oleh bank, yaitu dengan cara membandingkan antara aktiva produktif yang diklasifikasikan dengan aktiva produktif. Kemudian perbandingan penyisihan penghapusan aktiva produktif terhadap aktiva produktif diklasifikasikan. Rasio ini dapat dilihat pada neraca yang telah dilaporkan secara berkala kepada Bank Indonesia.

Untuk menghitung kualitas aktiva produktif digunakan rumus :

Bad Debt Ratio $(B D R)=$

Aktiva Produktif yang diklasifikasikan x $100 \%$

Total Aktiva Produktif

Selanjutnya angka kredit rasio aktiva produktif yang diklasifikasikan dihitung sebagai berikut :

$\mathrm{BDR}=15,5 \%$ atau lebih, nilai kredit $=0$

Setiap penurunan 0,15\%, nilai kredit ditambah 1 dengan maksimum 100

Bobot CAMEL untuk Bad Debt Ratio adalah 25\%.

Selanjutnya Cadangan aktiva yang diklasifikasikan dibentuk dengan menyisihkan sebagian laba yang merupakan persetujuan pemegang saham yang dilakukan dalam rapat pemegang saham.

Angka kredit rasio penyisihan (cadangan) penghapusan aktiva produktif yang diklasifikasikan dihitung sebagai berikut:

Rasio $=0$ (tidak ada cadangan / penyisihan), angka kredit $=0$

Setiap kenaikan sebesar 1\% angka kredit ditambah 1 dengan maksimum 100 Bobot CAMEL untuk penyisihan/cadangan aktiva yang diklasifikasikan adalah 5\%.

\section{Kredit Bermasalah}

Salah satu kegiatan usaha pokok bank dalam kegiatan pengalokasian dana adalah menyalurkannya dalam bentuk kredit kepada nasabah. Yang dimaksud kredit adalah penyediaan uang atau tagihan yang dapat dipersamakan dengan itu berdasarkan persetujuan atau kesepakatan pinjam - meminjam antara bank dengan pihak lain yang mewajibkan pihak meminjam untuk melunasi hutangnya setelah jangka waktu tertentu dengan jumlah bunga, imbalan atau pembagian hasil keuntungan.

Perkembangan pemberian kredit yang paling tidak menggembirakan adalah apabila kredit yang diberikan bank ternyata menjadi kredit bermasalah. Hal itu terurama disebabkan oleh kegagalan pihak debitur untuk memenuhi kewajibannya 
untuk membayar angsuran pokok kredit beserta bunga yang disetujui kedua pihak dalam perjanjian kredit. Oleh karena itu, kredit bermasalah dapat diartikan sebagai pinjaman yang mengalami kesulitan pelunasan akibat adanya faktor kesengajaan dan atau karena faktor eksternal diluar kemampuan kendali debitur

Ada beberapa indikasi kredit bermasalah / kredit macet, yaitu :

a. Terjadi penundaan dalam penerimaan laporan keuangan dan pembayaran

b. Keluarnya anggota eksekutif perusahaan.

c. Permintaan tambahan kredit, usaha nasabah yang terlalu ekspansif

d. Ditemukannya kegiatan ilegal atas usaha nasabah, dll

Kredit bermasalah dapat diukur dari kolektibilitasnya. Kolektibilitas merupakan gambaran kondisi pembayaran pokok dan bunga pinjaman serta tingkat kemungkinan diterimanya kembali dana yang ditanamkan dalam surat-surat berharga. Penilaian kolektibilitas kredit digolongkan ke dalam 5 kelompok yaitu: Lancar (pass), Dalam perhatian khusus (special mention), Kurang lancar (substandart), Diragukan (doubtful), Macet (loss).

Bank Indonesia menetapkan bahwa tingkat Net Performing Loan (NPL) yang wajar sebesar 5\% dari total kreditnya. Hal ini dapat disimpulkan bahwa bank dapat dikategorikan sehat apabila Net Performing Loan dibawah 5\% apabila rasio NPL berada di atas $5 \%$ dapat dikatakan bank tersebut tidak sehat.

Untuk mengetahui besarnya tingkat Net Performing Loan suatu bank maka diperlukan suatu pengukuran dengan menggunakan rumus sebagai berikut:

NPL $=\underline{\text { Kredit Bermasalah }} \times 100 \%$

Total Kredit

\section{Profitabilitas}

Profitabilitas adalah kemampuan perusahaan untuk menghasilkan laba dalam kegiatan operasinya merupakan fokus utama dalam penilaian prestasi perusahaan (analisis fundamental perusahaan) karena laba perusahaan selain merupakan indikator kemampuan perusahaan memenuhi kewajiban bagi para penyandang dananya juga merupakan elemen dalam penciptaan nilai perusahaan yang menunjukan prospek perusahaan di masa yang akan datang. Dari sini permasalahannya menyangkut efektifitas manajemen dalam menggunakan total aktiva maupun aktiva bersih seperti yang tercatat dalam neraca.

Efektifitas dinilai dengan menghubungkan laba bersih yang didefinisikan dalam berbagai cara terhadap aktiva yang digunakan untuk menghasilkan laba. Hubungan seperti ini merupakan salah satu analisis yang memberikan gambaran lebih, walaupun sifat dan waktu dari nilai yang ditetapkan pada neraca cenderung menyimpangkan hasilnya. Bentuk paling mudah dari analisis profitabilitas adalah menghubungkan laba bersih (pendapatan bersih) yang dilaporkan terhadap total aktiva di neraca.

Profitabilitas dapat diukur dengan rumus sebagai berikut : 


\section{ROA $=\underline{\text { Laba Sebelum Pajak }} \times 100 \%$ \\ Total Aktiva}

\section{Pengaruh Kualitas Aktiva Produktif dan Kredit Bermasalah Terhadap Profitabilitas}

Kualitas aset (aktiva) merupakan salah satu hal terpenting di dalam menentukan tingkat kredit yang diberikan untuk memperoleh profitabilitas. Aset bank terbagi menjadi dua jenis yaitu aktiva produktif dan aktiva non produktif. Aset digunakan sebagai alat untuk penilaian kualitas aktiva produktif.

Salah satu indikator untuk mengukur tingkat keuntungan (profitabilitas) bank dari segi penggunaan asset digunakan analisis Return On Assets (ROA), semakin besar ROA suatu bank, maka semakin besar pula tingkat kuntungan yang dicapai bank tersebut dari segi penggunaan asset.

Dari penjelasan tersebut dapat dilihat bahwa kredit bermasalah dapat mempengaruhi kemampuan bank untuk memperoleh profitabilitas. Artinya profitabilitas akan tergantung pada besar kecilnya kredit bermasalah yang dihadapi oleh bank.

Kualitas aktiva produktif dan kredit bermasalah akan berdampak pada tingkat kemampuan bank untuk memperoleh profitabilitas. kualitas aktiva produktif (KAP) dari perbankan selanjutnya menyebabkan menurunnya kemampuan perbankan untuk menghasilkan laba. Dengan demikian pengaruh kualitas aktiva produktif apabila meningkat maka profitabilitas bank akan meningkat sedangkan pengaruh kredit bermasalah meningkat akan mengakibatkan hilangnya kesempatan memperoleh pendapatan atau profitabilitas bagi bank.

\section{METODE PENELITIAN}

\section{a. Desain penelitian}

Desain penelitian dilakukan penelitian kausal (causal research) untuk mengetahui pengaruh antara satu atau lebih variable bebas (independent variable) terhadap variable terikat (dependent variable), dimana penelitian ini dilakukan untuk mengetahui pengaruh kualitas aktiva produktif dan kredit bermasalah terhadap profitabilitas.

\section{b. Hipotesis}

Hipotesis merupakan jawaban sementara terhadap rumusan masalah penelitian oleh karena itu jawaban yang diberikan masih berdasarkan teori yang relevan belum didasarkan pada faktor - faktor empiris yang diperoleh melalui pengumpulan data.

$\mathrm{H}_{0}$ : Tidak terdapat pengaruh yang signifikan dari aktiva produktif terhadap profitabilitas.

$\mathrm{H}_{\mathrm{a}}$ : Terdapat pengaruh yang signifikan dari aktiva produktif terhadap profitabilitas.

$\mathrm{H}_{01}$ : Tidak terdapat pengaruh yang signifikan dari kredit bermasalah terhadap profitabilitas. 
$\mathrm{H}_{\mathrm{a} 1}$ : Terdapat pengaruh yang signifikan dari kredit bermasalah terhadap profitabilitas.

\section{Populasi dan sampel}

Populasi dalam penelitian ini adalah perusahaan perbankan yang terdaftar Bursa Efek Indonesia. Sampel dalam penelitian ini adalah 60 laporan keuangan perusahaan perbankan pemberi pinjaman / kredit metode pengambilan sampel yang digunakan adalah purposive sampling.

\section{Metode Pengumpulan data}

Dalam penelitian ini pengumpulan data dilakukan dengan penelitian kepustakaan dan atas analisa yang dilakukan terhadap laporan keuangan yang datanya di dapat dari Bursa Efek Indonesia.

\section{Jenis Data}

Jenis data dalam penelitian ini adalah data sekunder, berupa laporan keuangan periode 2008 - 2012 perusahaan perbankan pemberi pinjaman.

\section{Populasi dan sampel}

Populasi dalam penelitian ini adalah perusahaan perbankan di Bursa Efek Indonesia. Sampel dalam penelitian ini adalah 60 laporan keuangan perusahaan perbankan pemberi pinjaman di Bursa Efek Indonesia. Adapun metode pengambilan sampel yang digunakan adalah purposive sampling.

\section{Operasional dan Pengukuran Variabel}

Berdasarkan kajian piustakan dan hipotesis, operasional dan indikator variabel penelitian sebagai berikut :

Kualitas aktiva produktif adalah semua bentuk aktiva dalam bentuk rupiah dan valuta asing yang dimiliki bank yang digunakan untuk memperoleh hasil (pendapatan) sesuai dengan fungsinya dengan indikator rasio aktiva produktif yang diklasifikasikan dengan total aktiva produktif (bad debt ratio)

Kredit Bermasalah adalah kredit yang dalam pelunasannya mengalami kesulitan atau hambatan pelunasan akibat adanya faktor - faktor kesengajaan atau karena kondisi di luar kemampuan debitur dengan indicator rasio kredit bermasalah dengan total kredit (net performing loan ratio)

Profitabilitas adalah kemampuan perusahaan untuk menghasilkan laba dengan indikator rasio laba sebelun pajak dengan total aktiva (return on asset ratio)

\section{HASIL DAN PEMBAHASAN}

\section{Uji Deskriptif / Statistik Deskriptif}

Statistika deskriptif akan memberikan gambaran umum terhadap data yang digunakan dalam penelitian ini. Sebelum melakukan pengujian hipotesis melalui 
pengujian model, terlebih dahulu melakukan pengujian terhadap kualitas data yang akan digunakan dengan uji asumsi klasik dan uji regresi linier berganda.

Data yang diperoleh dari hasil analisa deskriptif menunjukan rata - rata

bebas yaitu aktiva produktif dan kredit bermasalah, serta variabel terikat yaitu profitabilitas. Hasil analisa deskriptif dapat dilihat pada tabel 1 berikut ini.

Tabel 1

Depenelitian Data Penelitian

Descriptive Statistic

\begin{tabular}{|l|c|c|c|}
\hline & Mean & $\begin{array}{c}\text { Std. } \\
\text { Deviation }\end{array}$ & $\mathrm{N}$ \\
\hline Profitabilitas & .02138 & .009889 & 60 \\
Aktiva_Produktif & .04193 & .029547 & 60 \\
Kredit_Bermasala & .01516 & .009682 & 60 \\
h & & & \\
\hline
\end{tabular}

Dari Tabel dapat dijelaskan bahwa :

\section{a. Aktiva Produktif}

Pada tabel hail statistik deskriptif di atas dapat diketahui bahwa aktiva produktif memiliki angka rata - rata sebesar 0,04193 (rata - rata dari aktiva produktif bank pemberi kredit yang terdaftar di BEI selama tahun 2008 - 2012), sedangkan angka standar deviasi sebesar 0,029547 ( variasi data dari aktiva produksi bank pemberi kredit yang terdaftar di BEI selama tahun 2008 - 2012).

b. Kredit Bermasalah

Pada tabel hail statistik deskriptif di atas dapat diketahui bahwa kredit bermasalah memiliki angka rata - rata sebesar 0,01516 (rata - rata dari kredit bermasalah bank pemberi kredit yang terdaftar di BEI selama tahun 2008 2012), sedangkan angka standar deviasi sebesar 0,009682 ( variasi data dari kredit bermasalah bank pemberi kredit yang terdaftar di BEI selama tahun 2008 $-2012)$.

c. Profitabilitas

Pada tabel hail statistik deskriptif di atas dapat diketahui bahwa profitabilitas memiliki angka rata - rata sebesar 0,02138 (rata - rata dari profitabilitas bank pemberi kredit yang terdaftar di BEI selama tahun 2008 2012), sedangkan angka standar deviasi sebesar 0,009889 ( variasi data dari profitabilitas bank pembri kredit yang terdaftar di BEI selama tahun 2008 2012).

\section{Uji Asumsi Klasik}




\section{Uji Normalitas}

Normalitas ini dilakukan dengan tujuan untuk menguji apakah dalam sebuah model regresi variabel terikat dan variabel bebas mempunyai distribusi normal atau tidak. Model regresi yang baik adalah distribusi data normal atau mendekati normal. Apabila pada tabel scatterplot titik - titik mendekati garis diagonal, model regresi tersebut memenuhi uji asumsi klasik. Hasil uji normalitas dengan scatterplot Normal P-P Plot dengan regresi dapat ditunjukan pada gambar 1 berikut ini.

\section{Normal P-P Plot of Regression Standardized Residual}

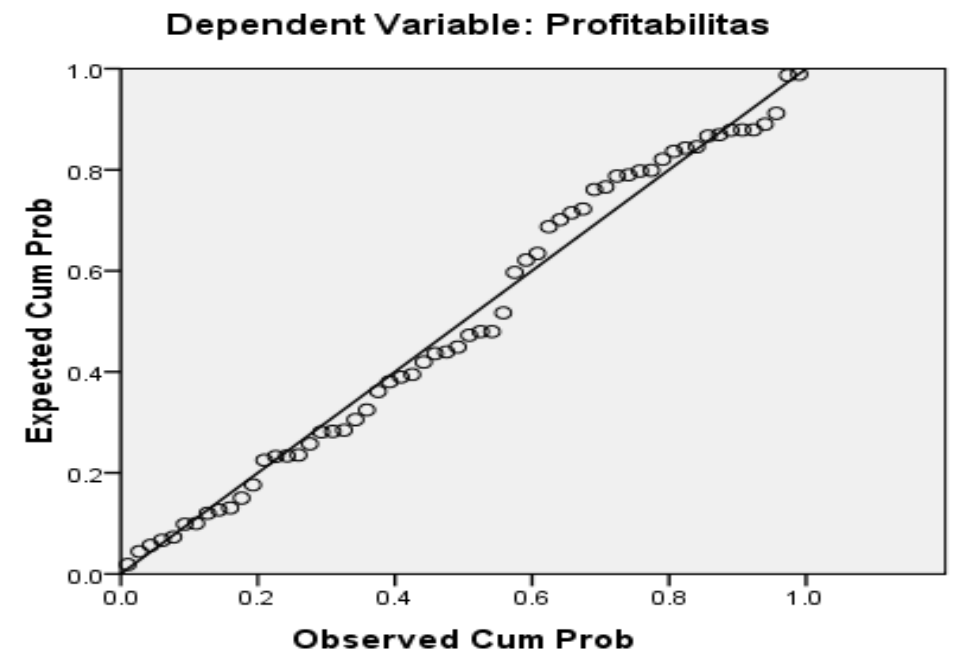

Sumber Output SPSS 17 (2014)

\section{Uji Multikolinieritas}

Multikolinieritas terjadi apabila nilai tolerance $>0,10$ dan Variance Inflaction Factor $(\mathrm{VIF})<10$. Berdasarkan tabel terlihat VIF seluruh variabel bebas lebih kecil dari 10. Sedangkan nilai nilai tolerance nya lebih dari 0,10 . Hal ini menunjukan bahwa variabel bebas dalam penelitian ini tidak saling berkolerasi atau tidak ditemukan adanya korelasi antara variabel bebas, sehingga model tidak mengandung multikolinieritas.

\section{Uji Heteroskedastisitas}

Dari gambar 3 scatterplot terlihat bahwa titik - titik menyebar secara acak serta tersebar baik di atas maupun di bawah angka 0 (nol) pada sumbu Y. Hal ini dapat disimpulkan bahwa tidak terjadi heteroskedastisitas pada model regresi (Ho diterima dan menola Ha). Sehingga model regresi yang dibuat penulis merupakan model yang 
valid dan layak digunakan untuk memprediksi profitabilitas berdasarkan masukan variabel bebas (independent variabel) dapat ditunjukan pada gambar 2 berikut ini.



\section{Uji Autokorelasi}

Tabel 2

Hasil Uji Autokorelasi

Model Summary

\begin{tabular}{|c|c|c|c|c|c|c|c|c|c|c|}
\hline \multirow[b]{2}{*}{$\begin{array}{l}\text { Mod } \\
\text { el }\end{array}$} & \multirow[b]{2}{*}{$\mathrm{R}$} & \multirow[b]{2}{*}{$\begin{array}{c}\mathrm{R} \\
\text { Square }\end{array}$} & \multirow[b]{2}{*}{$\begin{array}{l}\text { Adjusted } \\
\text { R Square }\end{array}$} & \multirow[b]{2}{*}{$\begin{array}{l}\text { Std. Error } \\
\text { of the } \\
\text { Estimate }\end{array}$} & \multicolumn{5}{|c|}{ Change Statistics } & \\
\hline & & & & & $\begin{array}{c}\mathrm{R} \\
\text { Square } \\
\text { Change }\end{array}$ & $\begin{array}{c}\mathrm{F} \\
\text { Change }\end{array}$ & df1 & df2 & $\begin{array}{c}\text { Sig. F } \\
\text { Chang } \\
\text { e }\end{array} \mid$ & $\begin{array}{l}\text { Durbin- } \\
\text { Watson }\end{array}$ \\
\hline 1 & $.103^{\mathrm{a}}$ & .011 & -.024 & .010008 & .011 & .306 & 2 & 57 & .738 & .750 \\
\hline
\end{tabular}

a. Predictors: (Constant), Kredit_Bermasalah, Aktiva_Produktif

b. Dependent Variable: Profitabilitas

Sumber : Output SPSS 17 (2014)

Pada tabel 7 dapat dilihat bahwa nilai Durbin Watson sebesar 0,750. Hal ini menunjukan bahwa tidak terdapat autokorelasi positif maupun negatif, yang berarti

bahwa model regresi tidak terdapat masalah autokorelasi.

\section{Uji Regresi Linier Ganda}

\section{a. Uji Parsial (Uji t-hitung)}


Tabel 3

Coefficients $\mathbf{s}^{\mathrm{a}}$

\begin{tabular}{|c|c|c|c|c|c|c|c|c|c|c|c|c|}
\hline \multirow[b]{2}{*}{ Model } & \multicolumn{2}{|c|}{$\begin{array}{l}\text { Unstandardi } \\
\text { zed } \\
\text { Coefficients }\end{array}$} & $\begin{array}{c}\text { Standardi } \\
\text { zed } \\
\text { Coefficien } \\
\text { ts } \\
\end{array}$ & \multirow[b]{2}{*}{$\mathrm{t}$} & \multirow[b]{2}{*}{ Sig. } & \multicolumn{2}{|c|}{$\begin{array}{c}95,0 \% \\
\text { Confidence } \\
\text { Interval for B } \\
\end{array}$} & \multicolumn{3}{|c|}{ Correlations } & \multicolumn{2}{|c|}{$\begin{array}{c}\text { Collinearity } \\
\text { Statistics }\end{array}$} \\
\hline & B & $\begin{array}{l}\text { Std. } \\
\text { Error }\end{array}$ & Beta & & & $\begin{array}{l}\text { Lower } \\
\text { Bound }\end{array}$ & $\begin{array}{l}\text { Upp } \\
\text { er } \\
\text { Bou } \\
\text { nd }\end{array}$ & $\begin{array}{l}\text { Zero- } \\
\text { order }\end{array}$ & $\begin{array}{c}\text { Partia } \\
1\end{array}$ & Part & $\begin{array}{c}\text { Toleran } \\
\text { ce }\end{array}$ & VIF \\
\hline (Constant) & $\begin{array}{r}.02 \\
0\end{array}$ & .003 & & $\begin{array}{r}7.0 \\
62 \\
\end{array}$ & .000 & .014 & .025 & & & & & \\
\hline $\begin{array}{l}\text { Aktiva_Pro } \\
\text { duktif }\end{array}$ & $\begin{array}{r}.03 \\
0\end{array}$ & .046 & .090 & $\begin{array}{r}.66 \\
4\end{array}$ & .509 & -.061 & .122 & .098 & .088 & $\begin{array}{r}.08 \\
8\end{array}$ & .935 & $\begin{array}{r}1.06 \\
9\end{array}$ \\
\hline $\begin{array}{l}\text { Kredit_Ber } \\
\text { masalah }\end{array}$ & $\begin{array}{r}.03 \\
2\end{array}$ & .139 & .031 & $\begin{array}{r}.23 \\
0\end{array}$ & .819 & -.247 & .311 & .054 & .030 & $\begin{array}{r}.03 \\
0\end{array}$ & .935 & $\begin{array}{r}1.06 \\
9\end{array}$ \\
\hline
\end{tabular}

a. Dependent Variable: Profitabilitas

Sumber : Output SPSS 17 (2014)

Hasil analisis regresi linier berganda pada Tabel pengujian t-hitung untuk masing masing variabel adalah sebagai berikut :

\section{Pengaruh Aktiva Produktif terhadap Profitabilitas}

Hasil pengujian mengenai pengaruh aktiva produktif terhadap profitabilitas menunjukan t signifikan 0,509 lebih besar dari tingkat signifikan 0,05 sehingga secara parsial struktur aktiva tidak berpengaruh signifikan terhadap profitabilitas.

\section{Pengaruh Kredit Bermasalah terhadap profitabilitas}

Berdasarkan hasil perhitungan regresi linier berganda diatas menunjukan bahwa selama periode pengamatan $(2008$ - 2012) variabel kredit bermasalah tidak berpengaruh terhadap profitabilitas bank - bank yang terdaftar di BEI.

Hal ini ditunjukan dengan besarnya signifikansi t signifikan sebesar 0,819 dimana signifikansi ini jauh lebih besar dari level signifikansi yang digunakan $(0,05)$. Hasil ini mengindikasikan bahwa kredit bermasalah pada periode pengamatan tidak berpengaruh terhadap profitabilitas.

Tabel 4

Hasil koefisien determinasi 
Model Summaryb

\begin{tabular}{|c|c|c|c|c|c|c|c|c|c|c|}
\hline \multirow[b]{2}{*}{$\begin{array}{l}\text { Mode } \\
1\end{array}$} & \multirow[b]{2}{*}{$\mathrm{R}$} & \multirow[b]{2}{*}{$\begin{array}{c}\mathrm{R} \\
\text { Square }\end{array}$} & \multirow[b]{2}{*}{$\left|\begin{array}{c}\text { Adjusted R } \\
\text { Square }\end{array}\right|$} & \multirow{2}{*}{$\begin{array}{c}\text { Std. } \\
\text { Error of } \\
\text { the } \\
\text { Estimat } \\
\text { e }\end{array}$} & \multicolumn{5}{|c|}{ Change Statistics } & \multirow[b]{2}{*}{$\begin{array}{c}\text { Durbin } \\
- \\
\text { Watso } \\
n\end{array}$} \\
\hline & & & & & $\begin{array}{c}\mathrm{R} \\
\text { Square } \\
\text { Change }\end{array}$ & $\begin{array}{c}\mathrm{F} \\
\text { Change }\end{array}$ & df1 & df2 & $\begin{array}{c}\text { Sig. F } \\
\text { Chang } \\
\mathrm{e}\end{array}$ & \\
\hline 1 & $.103^{\mathrm{a}}$ & .011 & -.024 & .010008 & .011 & .306 & 2 & 57 & .738 & .750 \\
\hline
\end{tabular}

a. Predictors: (Constant), Kredit_Bermasalah, Aktiva_Produktif

b. Dependent Variable: Profitabilitas

Nilai $r$ square $\left(\mathrm{R}^{2}\right)$ atau nilai koefisien determinasi digunakan untuk mengukur seberapa jauh kemampuan model dalam menerangkan variasi dependen. Nilai $\mathbf{R}^{2}$ adalah diantara nol atau satu. Nilai $\mathrm{R}^{2}$ yang kecil berarti kemampuan variabel independen dalam menjelaskan variabel dependen sangat terbatas. Nilai yang mendekati satu berarti variabel independen memberikan hampir semua informasi yang dibutuhkan untuk memprediksi variabel dependen.

Dari hasil pengujian hipotesis diketahui nilai $\mathrm{R}^{2}$ ( $\mathrm{R}$ square change) sebesar 0,011 mempunyai arti bahwa variabel dependen mampu dijelaskan oleh variabel independen sebesar $1,1 \%$. Dengan kata lain 1,1\% profitabilitas mampu dijelaskan oleh aktiva produktif dan kredit bermasalah, sedangkan sisanya 98,9\% dijelaskan oleh faktor lain yang tidak diikutsertakan dalam penelitian ini.

Nilai $R$ disebut juga dengan koefisien korelasi. Nilai R menerangkan tingkat hubungan antara variabel independen aktiva produktif dan kredit bermasalah. Dari hasil pengujian hipotesis diketahui nilai $\mathrm{R}$ sebesar 10,3\%, berarti bahwa hubungan antara faktor aktiva produktif dan kredit bermasalah terhadap profitabilitas sebesar $10,3 \%$. 


\section{b. Uji Simultan (Uji F-hitung)}

Tabel 5

Hasil Uji Simultan

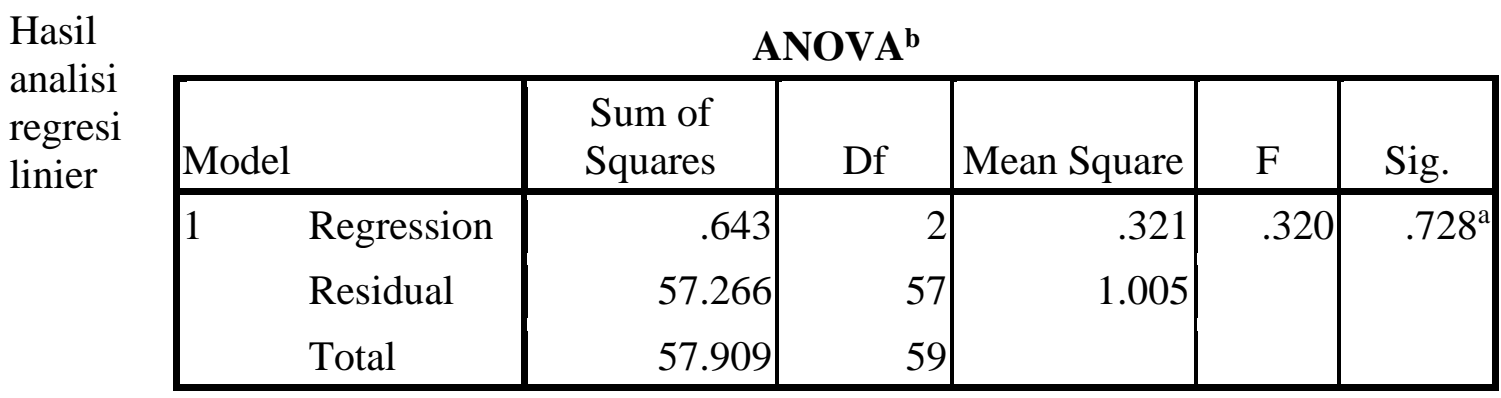

a. Predictors: (Constant), Kredit_Bermasalah, Aktiva_Produktif

b. Dependent Variable: Profitabilitas

berganda pada tabel 3 menunjukan tingkat signifikan $F$ sebesar 0,320 dengan taraf signifikan sebesar 0,728. Nilai signifikansi adalah diatas 0,05 yang menunjukan bahwa variabel bebas secara simultan tidak mempunyai pengaruh yang signifikan terhadap profitabilitas pada signifikansi 5\%.

Berdasarkan koefisien regresi untuk masing-masing variabel bebas (independen) dapat diintrepretasikan sebagai berikut:

1. Konstanta (a) $=0,020$. Hal ini menunjukan bahwa jika setiap variabel bebas aktiva produktif dan kredit bermasalah sama dengan nol, maka nilai dari profitabilitas mengalami kenaikan 0,020.

2. Koefisien regresi $b_{1}$ sebesar 0,030 menunjukan bahwa hubungan variabel aktiva produktif terhadap profitabilitas adalah positif. Dapat diartikan bahwa setiap kenaikan aktiva produktif akan diikuti oleh kenaikan sebesar 0,030.

3. Koefisien regresi $b_{2}$ sebesar 0,032 menunjukan bahwa hubungan variabel kredit bermasalah terhadap profitabilitas adalah positif. Dapat diartikan bahwa setiap penurunan kredit bermasalah akan diikuti oleh kenaikan sebesar 0,030.

\section{KESIMPULAN}

Dari hasil dan pembahasan penelitian yang telah dilakukan dapat disimpulkan bahwa :

1. Struktur aktiva produktif secara parsial tidak berpengaruh signifikan terhadap profitabilitas

2. Kredit bermasalah tidak berpengaruh signifikan terhadap profitabilitas bank - bank yang terdaftar di BEI. Hal ini ditunjukan dengan besarnya signifikansi t signifikan sebesar 0,819 dimana signifikansi ini jauh lebih besar dari level signifikansi yang digunakan $(0,05)$.

3. Variabel bebas (Aktiva produktif dan Kredit bermasalah) secara simultan tidak mempunyai pengaruh yang signifikan terhadap profitabilitas

4. Berdasarkan penelitian yang dilakukan penulis, dapat disimpulkan bahwa hasil R Square (R2) sebesar 0,011 mempunyai arti bahwa variabel dependen mampu dijelaskan oleh variabel independen sebesar 1,1\%. Dengan kata lain 1,1\% profitabilitas mampu dijelaskan 
oleh aktiva produktif dan kredit bermasalah, sedangkan sisanya 98,9\% dijelaskan oleh faktor lain yang tidak diikutsertakan dalam penelitian ini.

\section{DAFTAR PUSTAKA}

Stice dan skousen. 2009. Akuntansi Keuangan (Intermediate Accounting). Jakarta:

Salemba Empat

Toto Prihadi. 2010. Analisi Laporan Keuangan Teori dan Aplikasi. Jakarta : PPM.

Amin Widjaja Tunggal. 2012. Dasar - Dasar Analisis Laporan Keuangan. Jakarta: Harvarindo

Harahap, Sofyan Syafri. 2011. Analisa Kritis Atas Laporan Keuangan. Jakarta : PT. Raja Grafindo Persada

Prof. DR. Sugiono, 2010. "Statistik untuk penelitian”. Bandung : Alfabeta

Ikatan Akuntan Indonesia. 2007. Standar Akuntansi Keuangan. Jakarta : Salemba Empat

Duwi Priyatno. 2008. Mandiri Belajar SPSS (Statistic Product and Service Solution). Yogyakarta : Mediakom

Nugroho Agung Buhono. 2006. Strategi Jitu Memilih Metode Statistik Penelitian Dengan SPSS. Yogyakarta : Andi

Sudaryono dan Asep Saefullah. 2012. Statistik Deskriptif - Langkah Mudah Analisis Data. Yogyakarta: CV Andi Offset

Sangadji, Etta Mamang dan sopiah. 2010. Metodologi Penelitian Pendekatan Statistika dalam Penelitian. Edisi Pertama. Yogyakarta : CV Andi 